University of San Diego

Digital USD

Spring 5-23-2017

\title{
Considerations for Mexican Immigration Policy Reform: How \\ Motivations to Migrate Align with U.S. and Mexican \\ Macroeconomic Conditions
}

\author{
Alix Naugler \\ University of San Diego
}

Follow this and additional works at: https://digital.sandiego.edu/honors_theses

Part of the Defense and Security Studies Commons, Econometrics Commons, Economic Policy

Commons, Economic Theory Commons, International Economics Commons, Latin American Studies

Commons, Macroeconomics Commons, Policy Design, Analysis, and Evaluation Commons, Public Policy

Commons, and the Social Policy Commons

\section{Digital USD Citation}

Naugler, Alix, "Considerations for Mexican Immigration Policy Reform: How Motivations to Migrate Align with U.S. and Mexican Macroeconomic Conditions" (2017). Undergraduate Honors Theses. 40.

https://digital.sandiego.edu/honors_theses/40

This Undergraduate Honors Thesis is brought to you for free and open access by the Theses and Dissertations at Digital USD. It has been accepted for inclusion in Undergraduate Honors Theses by an authorized administrator of Digital USD. For more information, please contact digital@sandiego.edu. 
Considerations for Mexican Immigration Policy Reform: How Motivations to Migrate Align with U.S. and Mexican Macroeconomic Conditions

\author{
A Thesis \\ Presented to \\ The Faculty and the Honors Program \\ Of the University of San Diego
}

By

Alix Naugler

International Business

2017 


\begin{abstract}
The nationalistic rhetoric adopted by the newly-elected president's administration along with the public's climaxing anti-immigrant hysteria has recently forced Mexican immigration intervention to the top of the U.S. agenda. Misconceptions regarding Mexicans' role in stealing jobs, threatening cultural and ethnic traditions, and straining public welfare, educational, and healthcare resources have spurred a fear among the American people. This politically-fabricated "schizophrenia" has ceased the political and economic collaboration between the two nations and has resulted in the unilateral militarization of the U.S.-Mexico border. In this evaluation of the U.S. government's immigration policies, the proposed economic theories related to Mexicans' motivations in crossing the border, and the data collected from border-crossing participants, it is evident new policy measures need to be implemented to reflect these nuanced trends which stand contrary to conventional wisdom. This research examines the motivations of Mexican immigrants to cross into the U.S. using data collected by El Colegio de la Frontera Norte in collaboration with several Mexican government agencies. These parties conducted qualitative surveys with Mexican migrants that evaluate the dynamic, magnitude, and characteristics of the migratory flow across the U.S.-Mexico border. The analysis aims to evaluate if economic motivations are moderated by U.S. or Mexican macroeconomic conditions and if a trade-off exists between motivations for crossing, specifically if economic motivations and those related to social capital theory are substitutes and uphold an inverse relationship. Results indicate a classic trade-off does exist among motivations to cross under specific U.S. macroeconomic conditions and both economic and noneconomic motivations to migrate are influenced by U.S. but not Mexican macroeconomic indicators. Based on these findings, an analysis of specific policy reform measures and binational solutions needs to be considered for future legislation to help resolve this multifaceted reality in the long-term.
\end{abstract}




\section{Introduction}

The debate concerning Mexican immigration in the last decade has become bifurcated in nature, creating two distinct postures influenced by diverging ideological claims and emotional arousal. One on side, proponents of the suspension of Mexican immigration argue the surge of Mexican immigrants in the U.S. threatens the ethnic, political, and sociocultural composition of the U.S., negatively impacts U.S. economic infrastructure (as it fosters a growing dependence on "race to the bottom" practices and depresses nominal wages), places stress on natural resources stretched across a growing populous, and exponentially accelerates criminal activity (Light \& Togunde, 2008, p. 279). Fueled by the changing political landscape and selective coverage of the media, this group has painted the Mexican migrant population as a threat against pure "Americanism." Conversely, the opposing stance argues the integration of the Mexican population into the U.S. not only cultivates linguistic and cultural diversity but fosters essential U.S. macroeconomic growth. The pro-immigration defenders position Mexican immigrants as productive assets, largely performing work avoided by natives, providing a supply of cheap labor which translates into cost-saving benefits for consumers, and paying more in taxes than consuming in social services (Light \& Togunde, 2008, p. 280). These ideological discrepancies have shaped the national conversation regarding Mexican immigration. Historically, political figures have leveraged Americans' sensationalist fear of Mexican immigrants overriding the country to further a nationalistic discourse and grow their popularity within their party. The statistic sustaining the anti-Mexican immigrant hysteria within the U.S. population through shifts in the political landscape relates to the publicly-perceived "growing" undocumented immigrant population. The Pew Research Center in 2016 calculated that in 2014 (see Figure 1) the unauthorized immigrant population in the U.S. was 11.1 million and this population has stabilized since the end of the U.S. Recession in 2009 (Passel \& Cohn, 2016). Contrary to conventional wisdom, this estimation is not fully comprised of Mexican immigrants as only 52\% of this unauthorized population are of Mexican origin (Passel \& Cohn, 2016). While the total number of undocumented immigrants rises in the U.S. until 2007 (see Figure 1), the percentage of Mexican immigrants representing this undocumented population has continued to fall since compared to immigrants of other nationalities. This population most dramatically falls after its peak of 6.95 million in 2007 as seen in Figure 2 (Pew Research Center, 2016). This graphical depiction demonstrates the "reversal" pattern of the increasing illegal immigrant population in the U.S. However, despite this data-driven 
reality, distorted facts, misconstrued enthusiasm, and political fervor continue to taint the present immigration saga in the U.S. This narrative of the decline in the Mexican undocumented immigrant populous brings to question what driving forces play an impactful role in the deterrence and incentivization of Mexican migration to the U.S. and the facilitation of return migration back to Mexico. While proposed policy "quick fixes" such as the construction of a wall along the U.S.Mexico border and mass deportation seem to tarnish North Americans' Mexican immigrant anxieties, these attempts fail to evaluate or resolve the core of the Mexican immigration phenomenon: Mexicans' motivations to migrate.

While previous studies on Mexican immigration have focused on a quantitative assessment regarding the impact of Mexican migratory flows, prior research has yet to thoroughly apply a qualitative perspective. This nuanced approach prioritizes the evaluation of Mexicans' motivations to migrate to the U.S. as rationale to shape future policy initiatives. Thought leaders in this research domain consistently present findings grounded in the analysis of annual migration crossing figures and the effects Mexican immigration has on native employment conditions and wage prospects, disregarding the Mexican migrant's perspective and predominantly fixating on the "American" point of view (Borjas, 1990; Fix \& Passel, 1994; Borjas, 1994; Chiswick, 1978; Borjas \& Katz, 2005; Anderson \& Gerber, 2008; Escobar-Latapi, 2016). By reorienting the immigration conversation around exploring why Mexican migrants cross into the U.S., it helps determine the principal causes that spur transnational migratory flows across the U.S.-Mexico border. This perceptual shift in evaluation methodology posits policy considerations regarding the U.S. immigration system should complement Mexican migrants' personal rationalization in deciding to migrate - a framework yet to be recognized or implemented to any degree at the legislative level. This research focuses on testing Mexicans' economic and non-economic motivations to migrate to the U.S. against several U.S. and Mexican macroeconomic indicators to determine their impact on the decision to migrate. Based on several theories regarding international migration applied to the Mexican immigration narrative, it is hypothesized that favorable macroeconomic conditions in the U.S. will cause a demand-pull attraction facilitating the upward migration of Mexican immigrants to the U.S. While the motivations for immigration are multiple, this study focuses on economic and non-economic factors including family reunification and visitation and posits that a trade-off will exist between the economic and non-economic (familiar) rationale with regards to deciding to migrate. Overall, assessing Mexican migrants' reasons for traveling to the U.S. 
represents a nuanced approach in addressing the complexities of the Mexican immigration crisis and its growing polemics. Furthermore, an empirical analysis of these intrinsic and extrinsic motivations humanizes the national dialogue and proposed political action regarding Mexican immigration. It places value on the attitude and personal demeanor of the individual immigrant versus that of the society it aims to enter or assimilate into. Thus, considering Mexican migrants' intention in crossing into the U.S. and how these intentions change in response to shifts in the macroeconomic landscape provides a binational platform designed to balance the urgencies of the Mexican migrant population with the physical and human capital demand of the U.S.

\section{Literature Review}

To fully comprehend which forces facilitate the migration of Mexicans across the U.S.Mexico border, the mechanics of international migration need to be analyzed to reveal what internal and external elements play an integral role in the migration decision and to what extent. American sociologist and Princeton professor Douglas Massey has mapped out several theories regarding international migration and applied them to the Mexican immigration phenomena experienced in the U.S. Massey, Durand, and Malone (2002) in their work entitled Beyond Smoke and Mirrors: Mexican Immigration in an Era of Economic Integration, aimed to identify the forces in sending countries that promote out-migration, the forces in receiving countries that spur demand for immigrant labor, the motivations of international migrants who respond to these forces, and what social and economic infrastructures arise due to international migratory flows (p.9). The authors developed a comprehensive explanation for international migration derived from the application of neoclassical economics, social capital, new economics of labor, world systems, and segmented labor market theories. In assessing how these theories potentially motivate Mexicans to migrate to the U.S., these models serve as a basis for empirical analysis in this research to determine and ensure their applicable legitimacy.

\section{Neoclassical Economic Theory}

The common understanding of Mexican migration to the American public stems from the neoclassical economic theory which defines transnational movement as a simple cost-benefit decision uphold by rationality and derived from the binational wage gap (Massey \& Espinosa, 1997, p. 947). The theory and its extensions posit a macroeconomic and complementary microeconomic application exist which facilitates Mexican migration to the U.S. According to the 
macroeconomic extension, "migration stems from macro-level processes of [the] supply and demand" of labor between countries with unequal economic infrastructures (Light \& Togunde, 2008, p. 283). Thus, countries like the U.S. with large endowments of capital, scarce labor resources, and who offer better economic opportunities have higher wages than developing countries. Conversely, countries like Mexico who have limited endowments of capital relative to labor suffer from lower nominal wages due to the surplus of workers but scarcity of employment opportunities within the country. The U.S.'s shortage of low-skilled labor and high demand for it causes an increase in nominal wages in the U.S. relative to Mexico, increasing the binational wage gap between the two linked economies. This resulting international differential provokes migratory movement form the low-wage to the high-wage countries. As this upward movement of migrants to the higher-wage country persists, labor abundance grows in the U.S. which then depresses U.S. wages while labor scarcity in Mexico increases and consequentially nominal wages in Mexico begin to increase. This transnational movement of labor moderates an international wage gap based on these countries' fluctuations in their demand and supply of labor; it also reflects the financial and psychological costs of participating in migration (Massey, Durand, \& Malone, 2002, p. 9). The microeconomic extension of this theory assumes prospective Mexican migrants are rational thinkers with good information who develop a cost-benefit analysis to decide whether to migrate. In this process, migrants first compare what they expect to earn in wages in the U.S. against what wage they can maintain in their country of origin. Holding all else equal, if the U.S. wage holds a higher monetary value relative to that in Mexico, the migrant then must weigh the expected monetary and non-monetary benefits (higher productivity in terms of human capital investment and wages) against the anticipated monetary and non-monetary costs (transaction costs and psychological, cultural, linguistic, and occupational assimilation) of participating in international migration. The theory postulates that if the expected net return of this calculation yields a positive value, it would motivate a rational Mexican worker to migrate to the U.S. to exploit these perceived opportunities and pursue a higher standard of living (Massey, Durand, \& Malone, 2002, p.9). Thus, the theoretical apparatus of neoclassical economics indicates that if wages and productivity in the U.S. rise, it will entice Mexicans to assume the transactions costs and emigrate to take advantage of the more "favorable" economic conditions in the U.S.

Though the neoclassical economics model applied to Mexican immigration is most associated with an individual's migratory decision, the U.S. government has enacted several U.S. 
immigration policy measures derived from the principles of this theory to justify the further militarization of the U.S.-Mexico border. As the prospective Mexican migrant calculates the costbenefit analysis of migrating, the U.S. government has historically acted to deter Mexican migratory flow by raising the transactions costs (financial, psychic, and material) and reducing the perceived gains of crossing (Massey \& Espinosa, 1997, p. 940). In relation to the model, federal regulations which increase the perceived cost of crossing will — theoretically—dissuade Mexicans from migrating to the U.S. In reaction to these principles, U.S. authorities implemented several programs and laws in the twentieth century to reduce the net benefit of migrating to the U.S. and curtail illegal immigration (Massey \& Riosmena, 2010, p. 297).

Historically, U.S. authorities aimed to implement a strategy of prevention through deterrence to increase migration transaction costs specifically for the Mexican migrant population. The 1965 Amendments to the Immigration Nationality Act, for example, represent a practical manifestation of this theory. The legislation institutionalized family reunification as the objective for a new visa allocation system that disproportionately favored immigrants of U.S. families over skilled workers. It imposed an annual visa supply cap of 120,000 for countries in the Western hemisphere which forced Mexicans to compete with other Latin American immigrants for the same numerically restricted visa supply (Massey, Durand, Malone, 2002, p. 40). These measures implicitly increased transactions costs for prospective Mexican migrants as their probability of successful entry became limited by the decrease in the visa supply. As a result, costs regarding the application process increased in terms of fiscal value, time, and convenience. An infamous effort to control the illegal immigration of Mexicans, protect the economic security of the U.S. workforce, and promote the nation's sovereignty in response to the rising anti-immigrant climate was the passage of the Immigration Reform and Control Act (IRCA) in 1986. Its congressional measures allocated more financial capital, personnel, and other resources to the border to increase U.S. Border Control enforcement which increased the perceived probability of apprehension and deportation. Additionally, it imposed sanctions on U.S. employers who hired illegal immigrants, positioning U.S. jobs as less attractive and increasing the risks of migration (Massey \& Espinosa, 1997, p. 90). To further increase the transaction costs for Mexican migrants, various policies sought to bar legal and illegal Mexican immigrants' access to public assistance programs, public education, and emergency medical services (Fix \& Passel, 1994, p. 62-63). Furthermore, programs like Operation Blockage and Gatekeeper at the El Paso, Texas and San Diego, CA metropolitan 
crossing points respectively represented additional attempts to intensify border security through the implementation of advanced technological infrastructures and an increase in the supply of onfoot U.S. Border Control personal (Massey, Durand, \& Malone, 2002, p. 106). Based on the ramifications of the neoclassical economics model, the U.S.'s unilateral effort in militarizing the border should have decreased the perceived gains of legal or illegal entry. However, the reality of this abstract concept failed to materialize in modern practice.

While the application of the neoclassical economics model serves as the only basis of public understanding that explains why Mexicans migrate to the U.S., many academics dictate the theory by itself is not sufficient to evaluate the current immigration crisis. Analysis suggests that the practical manifestation of this theory does not hold empirically and that other theories and their implications are needed to paint a more comprehensive picture of this increasingly complex issue. In short, U.S. immigration reform has increased the transactions costs of immigration through border militarization but despite these imposing financial and physical barriers, Mexican illegal immigration has not only persisted but grown even in the absence of a wage differential (Massey \& Riosmena, 2010, p. 295; Massey \& Espinosa, 1997, p. 963; Massey, Durand, \& Malone, 2002, p. 10). The literature reveals Mexican migrants who do not have the monetary slack to enter the U.S. legally pursue entry through undocumented channels, crossing through uninhabited, less visible, and more rural settings which increases the probability of injury or death (Massey, Durand, \& Malone, 2002, p. 95-95, 113-114). This depicts the willingness of migration participants to assume additional costs in migrating to the U.S. despite the high-risk climate. By circumventing highly-monitored crossing points to avoid increased border enforcement measures, this suggests Mexican migrants perceive the potential gain of working in the U.S. as still large enough to offset the potential dangers of illegal immigration (Massey \& Riosmena, 2010, p. 297). Thus, these efforts geared towards deterrence have backfired while also further exacerbating the repercussions of the U.S. immigration crisis. Though efforts to increase transactions costs were intended to prevent the upward migration of Mexicans, it simultaneously yet unknowingly fostered permanent migration, ceasing the flow of circular migratory movement (Durand \& Massey, 2010, p. 27; Fernandez-Kelly \& Massey, 2007, p. 99). Based on unauthorized Mexican immigrants' perspective, they reduce cyclical movements of return migration to Mexico to spare themselves from the greater perceived risks of reentry, resulting in an unprecedented accumulation of Mexicans residing north of the border (Fernandez-Kelly \& Massey, 2007, p. 99). The neoclassical 
economic model fallaciously defines migrants as rational utility-maximizing actors who should want to permanently reside in the U.S. to reap the prosperity of increased economic opportunity. However, this simplistic account of permanent residency fails to observe the presence of several anomalies trumping the assumption of a one-way flow of long-term migrants: the increasing annual flows of remittances sent back to Mexico by migrants to increase the betterment of their families' lives and the incrementing outflow of Mexicans from the U.S. (Massey, Durand, \& Malone, 2002, p. 11, 62-63; Light \& Togunde, 2008, p. 285-285). Empirical analysis suggests the dynamic expansion of Mexican migration to the U.S. does not alone follow the simple changes in the objective benefits and costs of international migration as U.S. governmental attempts to curtail Mexican migratory flow based on these parameters have failed to do so. Since the effects of restrictionist indicators have yielded miniscule results, the impactful effects of other theories of international migration need to be considered to understand Mexicans' intrinsic motivations to migrate.

\section{Social Capital Theory}

A prominent theory widely acknowledged by the academic community relies on the rubric of social capital formation as the basis for the initiation and perpetuation of international migration. According to Massey and Espinosa (1997), social capital relates to the summation of resources available and gains to be accrued by an individual due to mutual relationships (p. 951). In application, larger family units in Mexican and Latin American societies embody social capital and extend those bonds within a narrow radius of trust comprised of family and personal friends (Fukuyama, 2001, p. 9, 11-12). For the Mexican migration narrative, having interpersonal ties with former or current U.S. migrants represents a valuable social asset that can be leveraged to obtain information and assistance that reduce the transaction costs and increase the expected net returns to international migration (Massey \& Espinosa, 1997, p. 951). According to this theory, knowledge is transferred between experienced and amateur migrants which decreases the associated risks of transnational movement. These migrant networks ultimately serve as vehicles of information and expertise that facilitate achievement in entry and assimilation in the U.S. labor market (Massey \& Espinosa, 1997, p. 952). Borjas (1990) explains how once a family member crosses into the U.S., they become a reliable and inexpensive source of information regarding U.S. social and economic conditions; this information is then transmitted back to the country of origin to educate other available network members (p. 177). Social capital provides a means of creating economic 
efficiencies and reducing transactions costs as those who participate in migratory knowledgesharing can bypass proposed formalities that increase the transaction costs of migration (Fukuyama, 2001, p. 10). Social capital theory also elicits a self-perpetuating nature that continues to promote and sustain Mexican migration. This dynamic indicates that with each consecutive wave of migrants successfully leveraging the provided information and resources of their migrant networks, it further decreases the costs (i.e. information and transactions) and raises the benefits (i.e. increased probability of finding work and inexpensive housing) associated with migration for the subsequent wave (Massey \& Espinosa, 1997, p. 952). Thus, each act of migration creates additional social capital or in other terms, more migration-based knowledge, to garner successful economic and social integration in the U.S. The aggregating effect increases the quantity and quality of social capital by expanding the migratory networks and providing information derived from a larger accumulation of U.S. migration experience.

The extension of social capital theory through these relational networks across the U.S.Mexico border also plays a statically significant role in fostering illegal immigration. Massey and Espinosa (1997) indicate the quantity of social capital at a prospective immigrant's disposal creates the most impactful effects on undocumented immigration (p. 957, 965). Therefore, membership in these social networks provides the cross-border coordination and resources to successfully facilitate illegal entry and help alleviate the risks of the increased militarization of the border. Massey and Riosmena (2010) observed the failure of U.S. enforcement efforts stems from the powerful influence of social capital which encourages unauthorized Mexican immigration despite increased efforts to provide more line-watch hours, supply more border personnel, or implement more deterring tactics (p. 319). Also, U.S. enforcement policies have indirectly helped sustain the social capital formation through the repercussions of the Immigration Control and Reform Act of 1986. IRCA granted amnesty to roughly 2.3 million undocumented immigrants in the U.S. with the overwhelming majority being of Mexican origin (Massey \& Espinosa, 1997, p. 952). Granting legalization to this large group laid the foundation for the rapid accumulation of social capital as the probability of Mexican residents having a relative or member of their social network legally residing in the U.S. dramatically increased. These now "legal" immigrants could sponsor the immigration - legal or illegal — of those within their migratory network, spurring additional migration on a larger scale. Therefore, social capital is shown to not only be a leading motivation for transborder movement but a prominent predictor of Mexican immigration as it serves as a self- 
perpetuating mechanism to foster the flow of migrants despite imposed restrictionist measures enacted by the U.S. government.

\section{New Economics of Labor Theory}

Another model helping to describe why Mexican immigrants participate in international migration stems from the new economics of labor theory which holds migratory movement as a function of collective strategies aimed to combat macro-level market failures. Instead of migrants taking advantage of the "temporary disequilibrium in geographically distinct labor markets" in terms of wage variability - as proposed by the neoclassical economics - the new economics of labor theory explains motivations to migrate in terms of managing risks and accessing capital (Massey \& Espinosa, 1997, p. 953). This theoretical reasoning positions migration as a form of insurance, protecting the economic well-being of family units from unforeseen risks by promoting income portfolio diversification. In application, to safeguard households from the occurrence of market failures (such as the devaluation of the peso, price inflation, or crop failure in Mexico) Mexican families can send members to different labor markets, such as the U.S. or the domestic economy, temporarily. In this way, the family can continue to accumulate income to secure economic earnings through remittances despite poor economic conditions in Mexico (Massey, Durand, \& Malone, 2002, p. 11). Thus, Mexican migration serves as a mechanism to manage the proposed risks of the market. Additionally, this understanding gives households the opportunity to access capital previously not available in their country of origin such as the ownership of land, businesses, or a home that will allow them to finance future production activities or purchases (Massey \& Espinosa, 1997, p. 954). International migration in this context derives from collectivism ideals that value communal interests over that of isolated actors. Therefore, migration to the U.S. is not only an attempt to grow lifetime earnings, but a strategy to increase the economic stability and positioning of the family through diversifying risks. Due to the vulnerable state of the Mexican population, with unreliable, volatile, and difficult to access credit, capital, and insurance markets, migrants depend on international migration as a source of alternative income to protect their families against "the vagaries of the business cycle and the dislocations of structural change" (Massey, Durand, \& Malone, 2002, p. 11-12). Thus, macro-level forces exogenous to family units help propel migration to the U.S. as families aim to ensure financial security that precedes the market. 


\section{Worlds Systems and Segmented Labor Market Theory}

Both the world systems and segmented labor market models assume global and macrolevel conditions outside the realm of individual control and influence are sources of international migration. The world systems theory dictates international migration stems from the changing structure and scope of the global economy and countries' active participation in globalization. The theory indicates global capitalist developments serve as disruptive forces which elicit social and economic transitions that ultimately displace individuals from their traditional livelihoods and impel them to participate in transnational labor markets out of necessity (Massey \& Espinosa, 1997, p. 955). Massey, Durand, and Malone (2002) argue market expansion constitutes large mobile populations apt to migrate to follow opportunities of employment as these global developments may undermine the productivity of local economies (p. 13). In the context of Mexican migration, globalization creates economic linkage between the U.S. and Mexico, facilitating the movement of Mexican migrants to the U.S. to meet the proliferating labor demands of the developed economy. The segmented labor market theory argues migration results from inherent macroeconomic "pull" factors prevalent in developed economies as there exists a built-in demand for immigrant labor to foster the prosperous progression of advanced industrial societies (Massey \& Riosmena, 1997, p. 954-955). In the Mexican migration narrative, the demand of unskilled workers by U.S. employers spurs the upward migration of Mexican migrants as U.S. businesses and industries have developed a chronic need for the abundant supply of low-wage laborers (Massey, Durand, \& Malone, 2002, p. 15). Massey, Durand, and Malone (2002) explain that since natives perceive poor wages, low occupational advancement, and harsher work environments as unattractive, Mexican migrants fill this labor void as they do not obtain the intrinsic motivation to work solely to achieve upward social mobility but see employment as simply a means to earn income (p. 15-18). This sought-after labor force allows U.S. firms to lower operational costs and increase their bottom line when production needs surge yet easily dispose of these workers in response to declining demand, objectifying them as simply a means to an end (Massey, Durand, \& Malone, 2002, p. 16). Regarding motivations to migrate, these theories posit Mexican migrants' personal desires to cross into the U.S. are weaker forces than the external conditions shaping the interaction of global economies.

In analyzing these various methods that suggest several relational and structural forces spur international migration, the following was hypothesized regarding the ramifications of 
neoclassical economics and the social capital theory. First, favorable changes in the U.S. macroeconomic environment will facilitate a demand-pull motion stimulating upward Mexican migration. Second, because of the prevalence and statistically significance of these two theories in the literature, a trade-off will exist between the economic and non-economic (familiar) rationale with regards to motivations to migrate to the U.S. The research purpose is to determine if the individual motivations of migration participants align with the manifestations postulated by neoclassical economics and the social capital theory. By testing Mexicans' personal motivations against changes in the U.S. and Mexican economic landscape, it will reveal migrants' primary reasoning in crossing and lead to an evaluation of current policy measures that monitor migratory flow and future policy recommendations to better facilitate this binational movement.

\section{Empirical Framework}

\section{Data Source}

The data utilized for this research came from the Survey of Migration at Mexico's Northern Border (EMIF Norte), a collaborative project which began in 1993 between El Colegio de la Frontera Norte (COLEF), the National Population Council, the Secretariat of Labor and Social Welfare, and other government departments in Mexico. The ongoing study aimed to increase understanding of the phenomena of labor migratory flows between Mexico and the U.S. and identify the flow's characteristics, volume, trends, and determine its impactful effects on the labor market in both neighboring societies (COLEF, 2013, p. 9-10). Representatives from these involved institutions have conducted daily ethnosurveys with various Mexican residents to collect demographic attributes and migration-specific information regarding their migration trips across the U.S.-Mexico border. Based on the chosen analytical framework, the "Migrantes Procedentes del Sur" database was selected which surveys Mexican residents who engage in the migratory flow from Southern Mexico to the Northern Border region in Mexico (see Figure 3). This surveyed population is comprised of Mexican residents 15 years of age or older, born in Mexico, who do not live in the city of the interview, whose movement to the Northern Border region or the U.S. stems from specific motivations, and who have no expected date of return to their place of habitual residence (COLEF, 2013, p. 43). In turn, this population is further classified according to participants' final migration destination: those bound to a Mexican city in the Northern Border region and those bound to the U.S. To test why Mexican migrants desire to enter the U.S., the 
filtered data set used in the empirical analysis only included observations of those who migrated to the Northern Border region to leverage it as a crossing point into the U.S. from January 2010 to September 2016.

Based on the outcomes depicted in Figure 4, the "Migrantes Procedentes del Sur" data for the specified timeline indicates a sudden drop in the percentage of Mexican residents motivated to migrate to the Norther Border region to continue in crossing into the U.S. Figure 4 represents the percentage allocations of reasons why Mexican migrants came to the Northern Border region in Mexico between January 2010 and September 2016. In examining the trend lines for the various motivations - such as to work or look for work, reunite with family and friends, study, or change residency - the percentage of Mexican migrants indicating their primary intention in traveling north was because they were in transit to the U.S. drastically declined after September 2015. This $77 \%$ decrease in a two-month span represents a severe deviation from the south-to-north migration narrative within Mexico compared to preceding years. Though the principle explanation for this shift remains ambiguous, in June 2015, then-presidential hopeful Donald Trump announced his candidacy for U.S. president (Diamond, 2015). During his presidential announcement speech, he infamously positioned Mexico, its government, and its population as robbers of American jobs, disproportionate benefactors of global trade, and the source of corruption jeopardizing U.S. security and curbing U.S. economic progress (Ye Hee Lee, 2015). Due to the ramifications depicted in Figure 4, it suggests the decrease in Mexican residents' willingness to migrate to the U.S. is a potential reaction to the anti-immigrant climate expressed in the U.S. political sphere, halting any large-scale migratory movement from Mexico.

In analyzing the filtered data of the "Migrantes Procedentes del Sur" database, which only includes Mexican migrants who indicated their travel to northern Mexico was only to cross into the U.S., similar irregular fluctuations in motivations to migrate trends occurred. Figure 5 shows the percentage of Mexican residents from the sampled population indicating their reason for migrating to the U.S. from January 2010 to September 2016. The following motivations are represented in these observations: to work, to look for work, to reunite with family or friends, to shop or conduct business, to study, and to change residency. The motivations for crossing into the U.S. "to work" (migrants who already acquired a position in the U.S. and thus in participating in upward migration from Mexico, they are solely fulfilling that employment obligation) and "to look for work" (migrants who have not received any form of formal employment upon migration and 
thus desire to cross into the U.S. to find work) represent manifestations of the neoclassical economic theory. These economic motivations express Mexican migrants' aspiration to enter the U.S. to exploit the binational wage gap and leverage the proliferating demand for low-skilled labor. The motivation for migrating to the U.S. "to reunite with family and friends" represents a noneconomic motivation and a phenomenon of the social capital theory. In application, when migrants cross to visit family and close friends, they strengthen their social networks and participate in knowledge-sharing which help decrease the transaction costs for latter waves of migrants. As Figure 5 demonstrates, From January 2010 till roughly September 2015, the variation in the percentages of Mexican residents' motivations for migrating to the U.S. illustrates a consistent narrative. However, after this date, the motivations of migrating to the U.S. to work, look for work, and reunite with family and friends begin to converge, reflecting changes in the Mexican migrants' perspective. The net results indicate the motivation to look for work has drastically fallen, while that for already having work and visiting family and friends has shown an increase relative to previous years. While the causation of these deviations remains unclear, speculation suggests with recent changes in the U.S. political landscape and the more apparent protectionist rhetoric utilized among the American people, Mexican migrants may perceive it too risky to migrate to the U.S. for more "optimistic" reasons such as looking for work. Conversely, the graph portrays Mexican migrants' willingness to migrate to the U.S. for more knowable or legitimate reasons, such as already having employment or having family or friends to visit in the U.S., increases as the anticipated risk seems to decline.

\section{Methodology and Descriptive Statistics}

To test the manifestations of the neoclassical economic and social capital theories, represented as the economic and familiar-based motivations to migrate respectively, a Probit regression model was run to analyze these reasons for crossing against U.S. and Mexican macroeconomic conditions. Specifically, equation (1) tests the economic motivation while equation (2) tests the non-economic (familiar) motivation to migrate to the U.S.

$\operatorname{Pr}($ Economic Motivation $=1)=\Phi\left(\beta_{0}+\beta_{1}\right.$ Male $+\beta_{2}$ Younger than $30+\beta_{3}$ Crossed Alone + $\beta_{4}$ Can Read/Write $+\beta_{5}$ Spoke English $+\beta_{6}$ Frequency of Cross $+\beta_{7}$ US UR $+\beta_{8}$ MX UR $+\beta_{9} \mathrm{US}$ GR $+\beta_{10} \mathrm{MX}$ GR)

$\operatorname{Pr}($ Non-economic $($ Familiar $)$ Motivation $=1)=\Phi\left(\beta_{0}+\beta_{1}\right.$ Male $+\beta_{2}$ Older than $30+$ $\beta_{3}$ Crossed Alone $+\beta_{4}$ Can Read/Write $+\beta_{5}$ Spoke English $+\beta_{6}$ Frequency of Cross $+\beta_{7} \mathrm{US}$ $\mathrm{UR}+\beta_{8} \mathrm{MX} \mathrm{UR}+\beta_{9} \mathrm{US}$ GR $+\beta_{10} \mathrm{MX}$ GR) 
Running Head: CONSIDERATIONS FOR MEXICAN IMMIGRATION POLICY REFORM

As seen in Table 1, descriptive statistics included 44,017 observations from Mexican migrants and captured basic demographic characteristics (gender, age, ability to read and write in any language, and ability to speak English), migration-specific traits (frequency of crossing the U.S.-Mexico border and whether migrants crossed alone or with others), and macroeconomic indicators of both countries (monthly unemployment rate and quarterly GDP growth rate). The macroeconomic variables for the U.S. and Mexico will be used to determine if Mexican migrants' motivations to migrate align or are impacted to any degree by the respective economic climates of these linked economies.

\section{Results}

\section{Model I}

In the first Probit regression analysis, the economic motivation (41,936 observations in total), which represents Mexican migrants who wished to migrate to the U.S. to look for work or to work, was tested against the demographic, migration-specific, and macroeconomic variables listed in Table 1. The results, shown in Table 2, indicate both the U.S. unemployment rate and the U.S. quarterly GDP growth rate were statistically significant. This suggests that an increase in the U.S. unemployment rate is associated with a decrease in the probability of Mexican migrants crossing for economic reasons. Similarly, an increase in the U.S. quarterly GDP growth rate is associated with an increase in the probability of crossing for economic reasons. Both economic variables have the expected sign. In evaluating the demographic and migration-based variables, Mexican migrants who crossed into the U.S. to work or seek employment are more likely to be male, younger than 30 years old, not able to read and write, not able to speak English, and have crossed the U.S.-Mexico border less frequently in their lifetime. Applying these conclusions to the theories of international migration, they represent a consistent narrative to the neoclassical economic theory explained earlier. For example, with a higher U.S. unemployment rate, the transactions costs to migrate increase as from the Mexican migrants' perspective, it is less likely to find and retain employment in the U.S. as the demand for laborers decreases. When U.S. GDP growth rate is positive, it increases the perceived benefit of crossing due to the assumption that the U.S. is maintaining a healthy economic environment that prospective migrants can exploit to obtain employment. Thus, changes in the U.S. macroeconomic condition influence Mexicans' migration decisions. If Mexican residents are motivated to migrate to the U.S. for economic 
reasons, favorable U.S. economic conditions facilitate a "pull" and unfavorable U.S. economic conditions curb migratory flow.

\section{Model II}

In the second Probit regression, the economic motivation to migrate is tested against the various years represented in the data set to determine if Mexican migrants' decision to cross for economic reasons is significantly influenced by the year. The results, shown in Table 2, indicate from 2011 to 2014 there is a monotonic increase in the likelihood of Mexican residents crossing to the U.S. for economic reasons compared to 2015 and 2016. As seen in Figure 6, Mexican residents were the least likely to migrate to the U.S. for economic reasons in 2011 (compared to 2015 and 2016) as demonstrated by the coefficient -.18. However, as time progresses (see Figure 6), the probability of crossing for economic reasons not only increases but the coefficients for these respective years get more positive and larger in value as the U.S. gradually recovers from the Great Recession. In application, this makes practical sense as 2010 and 2011 represented the tail-ends of the U.S. recession that lasted from December 2007 until June 2009 officially (U.S. Bureau of Labor Statistics, 2012). Yet, the lagging consequences still manifest in later years and these repercussions continued to strongly influence Mexican residents' migratory decision even after the Great Recession "formally" ended though in a diminishing way. This extrapolation empirically demonstrates migrating for economic reasons is heavily shaped by U.S. macroeconomic conditions, specifically by this most recent U.S. economic downturn. Additionally, as the negative effect of the U.S. Great Recession diminished, so, too, did the negative effect on this motivation for immigration to the U.S., as the negative coefficients for ensuing years became positive by 2013 and 2014.

\section{Model III}

In the third Probit regression analysis, the familiar (non-economic) motivation to migrate was tested against the demographic, migration-specific, and U.S. and Mexican macroeconomic indicators summarized in Table 1. Again, this motivation represented a phenomenon of the social capital theory in which the reason for migratory flow stems from reuniting with family and friends who resided in the U.S. The results in Table 2 show the U.S. unemployment was the only macrolevel variable to hold statistical significance. The positive coefficient suggests any increase in the U.S. unemployment rate is associated with an increase in the probability of crossing to the U.S. to 
reunite with family in friends. This finding indicates that in poorer U.S. economic conditions, prospective Mexican migrants might perceive it too risky to migrate to the U.S. with the intent of finding employment and will most likely cross to visit family instead. Validating the ramifications of the social capital theory, these results posit despite disadvantageous macroeconomic indicators, Mexican residents are still willing to migrate to the U.S. to further facilitate the transmission of migration-specific information. As a result, this knowledge transfer from U.S. residents to prospective immigrants will continue facilitate migration across the U.S.-Mexico border. Historically, this is also consistent with the narrative of U.S. border enforcement in which regardless of unfavorable conditions - whether policy measures aimed in militarizing the border or a high U.S. unemployment rate in the case of this research-Mexican migratory flows have endured (Massey \& Espinosa, 1997, p. 963; Massey \& Riosmena, 2010, p. 295). Thus, the results further emphasize the significant impact social networks have on propelling and sustaining Mexican migration as they represent a discrete yet powerful force not fully recognized or leveraged at the legislative level.

\section{Policy Implications}

Based on outcomes of the regression analyses, there are several policy implications to consider which can counteract these data-driven trends and contribute to a more efficientlymanaged U.S.-Mexico border. In the first regression model (Table 2), the data indicate from 20102016 favorable U.S. macroeconomic conditions (such as an increasing U.S. quarterly GDP growth rate) represent a "demand-pull" indicator. These strong demand-pull or neoclassical economic forces facilitate Mexican migration as they encourage Mexican residents to cross into the U.S. to benefit from these economically optimistic circumstances. (Anderson \& Gerber, 2008, p. 54). This assumes prospective Mexican residents who desire to cross for economic reasons unilaterally assess U.S. macroeconomic conditions prior to making a migratory decision and disregard the state (favorable or unfavorable) of their own domestic economy. One policy suggestion to decrease migrants' dependency on the U.S. economic climate in choosing to cross is to focus on pro-growth strategies for the Mexican economy, such as foreign direct investment (FDI) in Mexico. U.S. investment - resulting in possible job creation and economically-sound regulations - can increase economic efficiencies in Mexico by potentially narrowing the wage and development gap between the two countries. This action would help decrease the incentives to migrate if the economic situation between the countries was more comparable. Specifically, Massey and Espinosa (1997) 
indicated that growth of direct foreign investment in Mexico reduces rather than increases the odds of undocumented migration at the national level by "possibly creating jobs that provide domestic alternatives to emigration" (p. 963). Furthermore, while investing in Mexico's economic infrastructure can reduce the influential power of U.S. macroeconomic conditions in the migration decision, it also limits the probability of "supply-push" factors facilitating movement across the northern border. In theory, the constitution of a more stable economy in Mexico reduces the risk of domestic economic uncertainties such as unprecedented currency devaluations, high price inflation, or sudden job loss (Anderson \& Gerber, 2008, p. 56). The attempt to remove these economic ambiguities by reinforcing economic frameworks will cease to "push" Mexican migrants from their domestic communities. Thus, FDI counters the ramifications of the new economics of labor theory as it halts participation in international migration even with favorable U.S. economic conditions present. Initiating FDI would help narrow the twin gaps in economic infrastructure and income and reduce Mexican migratory flow to the U.S. (Anderson \& Gerber, 2008, p. 217). Overall, FDI can be leveraged to combat the manifestations of neoclassical economics and safeguard Mexico from unintentionally promoting international migration through economic policies that create uncertainty.

However, results presented here suggest the demand-pull forces are very strong and may persist despite economic conditions in Mexico. For instance, U.S. President Trump's "America First" agenda - his platform for a broader rejection of globalization that represents a deliberate effort to serve predominantly U.S. interests in terms of foreign policy, national security, and net economic benefit — plays an impactful role in the Mexican immigration narrative ("American First Foreign Policy," 2017). Specifically, an unintended consequence of Trump's campaign promise to renegotiate the provisions of NAFTA or withdraw from the multicountry trade agreement altogether is that it may make Mexico's economy worse off. With Trump's administration prioritizing economic nationalism, a renegotiation aimed to "put America first" might cause Mexico's economic infrastructure to give way, resulting in the exacerbation of Mexican unemployment and poverty rates due to Mexico's high economic dependency on the U.S. (Faux, 2017). Ironically, this agenda unintentionally drives more Mexican immigrants to the U.S. looking for work due to Mexico's resulting economic state. Thus, with the U.S. government aiming to negotiate trade agreements that create favorable U.S. labor conditions (such as increased wages 
and ensured job security for its own citizens), these objectives create a demand-pull attraction which still facilitate Mexican migration to the U.S.

While most Mexican residents expressed intentions to migrate to the U.S. for economic reasons, current U.S. legislation does not provide a legal or enforceable means to sustain labor mobility or repeat migration across the border. The data in Figure 5 shows that from January 2010 until October 2015, over $90 \%$ of the surveyed population indicated economic motivations (to work and to look for work) for migrating to the U.S. while from November 2015 to September 2016, economic reasoning for crossing represented anywhere from $62 \%$ to $100 \%$ of the surveyed population. These statistics indicate the prominent reason to migrate to the U.S. from Mexico is to work and look for work. However, current U.S. migratory policies aim to combat this effect through continuous border enforcement instead of enacting policies that complement this trend. This aggravates the serious damage to the economic, social, and political fabric of both countries (Massey, Durand, \& Malone, 2002, p. 105). Presently, without crossing illegally, Mexican residents can apply for a permanent resident visa to work in the U.S. - exacerbating the extent of permanent migration - or apply for a tourist visa and overstay their allotted welcome to seek employment (Massey, Durand, \& Malone, 2002, p. 159; Fix \& Passel, 1994, p. 70). Interestingly, entering legally and then overstaying a tourist visa represents the leading form of illegal Mexican immigration to the U.S., not physically crossing the U.S.-Mexico border clandestinely (Fix \& Passel, 1994, p. 4). Thus, no border wall-no matter how large-would prevent this from occurring. Furthermore, legal visa supplies for Mexico only sufficiently cover $9 \%$ of potential Mexican demand, insinuating a large share of migration is achieved through illegal means (Massey \& Espinosa, 1997, p. 957). Contrary to conventional wisdom, the Mexican perspective demonstrates a consensus that migrating to the U.S. to work represents a recurrent strategy. Mexican migrants' disinterest in permanent migration is supported by a large percentage of them sending remittances, or migradollars, back to their home communities and the vast repatriation of U.S. savings when they return to Mexico (Massey, Durand, \& Malone, 2002, p. 62). In 2015 alone, remittances accumulated to $\$ 24.8$ billion, representing 2.3\% of Mexico's GDP and replacing oil revenues as the largest source of foreign income (Browne, 2017; Associated Press, 2016). Additionally, $33 \%$ of undocumented Mexican migrants return within one year while roughly $85 \%$ of Mexican migrants return within 5 years (Massey \& Espinosa, 1997, p. 983). Thus, these findings position migration to the U.S. as transient in nature, allowing Mexican migrants to make gains 
from the binational wage gap and protect their families' assets from uncertain economic conditions temporarily. With the research reflecting the association of circular migration with economic motivations to migrate, U.S. policy measures need to be reoriented to cater to this phenomenon.

A solution to Mexican migrants' intrinsic and economically-motivated desire for temporary transnational movement is the implementation of a temporary visa worker program in the U.S. Massey and Espinosa (1997) indicate a larger supply of visas available to the Mexican population greatly reduces the odds of undocumented migration as the current restriction of the visa supply by U.S. authorities forces Mexican migrants to pursue riskier and unauthorized forms of entry to satisfy economic motivations (p. 963). Thus, the supply of these visas would help direct much of the migratory flow through legal channels. Moreover, a guest-worker program would make the need for employer sanctions established under the Immigration Reform and Control Act (IRCA) which criminalizes the hiring of undocumented workers-obsolete (Massey, Durand, \& Malone, 2002, p. 159). The widespread reluctance by employers to enforce these provisions and the sanctions' inability to reduce undocumented hiring supports their own futility (Massey, Durand, \& Malone, 2002, p. 160) The eradication of these provisions in conjunction with a temporary worker visa program grants Mexican migrants the legal right to work in the U.S. for a predetermined period as their entry and employment no longer signify a violation of law. Furthermore, due to U.S. businesses' high dependence on the lower-wage employment of Mexican immigrants, this program will provide a legal means to satisfy this labor demand in the U.S. economy. Yet, unlike the Bracero program, these visas would require U.S. firms to uphold and ensure employee protections that would prevent various forms of labor exploitation from occurring (Hernandez, 2009, p. 26). Another benefit from this program would be the creation of additional streams of revenue for the U.S. government. For example, the U.S. can attach a fee to the temporary worker visa, providing instant U.S. revenue and ensuring a cheaper and safer means for Mexican migrants to migrate in comparison to the cost and potential dangers of using a coyote, a guide that facilitates informal border-crossing into the U.S. through illegal avenues (Massey, Durand, \& Malone, 2002, p. 160). The prominence of Mexican migrants wishing to seek employment in the U.S., as shown in Figure 5, suggests a high demand for these temporary worker visas would follow. Other revenue gains include withholding taxes from these temporary workers' paychecks and the demilitarization of the U.S.-Mexico border due to the newly infrequent occurrence of undocumented immigration (Massey, Durand, \& Malone, 2002, p. 160). Shifting 
resources and personnel away from the border and to the interior of the U.S. de-incentivizes employers from hiring unauthorized workers and strengthens internal enforcement measures to more efficiently control the existing illegal population within the U.S. (Massey, Durand, \& Malone, 2002, p. 162). Overall, the implementation of this program helps restore circular migration instead of promoting linear transnational movement while matching willing Mexican workers with willing U.S. employers (Anderson \& Gerber, 2008, p. 221).

The data suggests social capital formation represents a potent force propelling Mexican migration despite unfavorable U.S. macroeconomic conditions, and to curb the extent of this phenomenon, a re-evaluation of the current visa allocation system is needed. From 2010-2016, even with a high U.S. unemployment rate, Mexican migrants still expressed intentions to cross the northern border to visit family and friends in the U.S. (see Table 2). This manifestation of social capital theory indicates U.S. macroeconomic factors are not a deterrent for Mexican migration like they are for those motivated by economic reasons. Namely, the poor U.S. economic climate does not play an impactful role in Mexican residents' migratory decision if they embody familiar-based motivations to migrate. With the disposal of the country-specific quota system, the 1965 Amendments to the Immigration and Nationality Act institutionalized family reunification as a primary objective of the U.S. visa allocation system (Borjas, 1990, p. 31). For all immigrants, the provisions require $80 \%$ of visas go to "close" relatives of U.S. citizens or residents while the remaining $20 \%$ go to those obtaining desirable skills sought after by U.S. companies or which meet U.S. economic needs (Borjas, 1990, p. 177). Additionally, these terms facilitate unregulated entry of immediate relatives of U.S. citizens, enabling them to bypass immigration formalities and sponsor the entry of an increasing number other family members (Borjas, 1990, p. 31-32). Those who benefit from this kinship bias in the preference system increasingly make visas more expensive and competitive for other prospective immigrants. In the Mexican migration narrative, these provisions facilitate social capital formation and foster chain migration as with an increasing number of relatives residing in the U.S., this decreases transactions costs and explicitly encourages the migration of additional family members (Borjas, 1990, p. 184). Prospective Mexican residents can simultaneously leverage the favorable U.S. visa system and the informational exchange from those within their social network to successfully cross into the U.S. The current system's parameters set the basis for the multiplier effect, exponentially fueling immigration based on 
family ties, and make U.S. macroeconomic forces ineffective in curbing Mexican migration. Thus, the U.S. visa allocation system is insufficient in resolving the current Mexican immigration crisis.

Replacing the currently rigid policy approach with a sliding scale mechanism to determine visa allocations can limit the ramifications of social capital theory while favoring skilled immigrants who can contribute to U.S. economic growth. Borjas (1990) advocates to change America's offer in the immigration market to attract a more skilled immigrant flow which will translate to higher financial gains to the U.S. economy (p. 162). In relation to this conjecture, the percentage of visas allocated to family and skilled workers should be determined by the favorability of U.S. economic conditions. With the adoption of a scale approach which adjusts to changes in the macroeconomic climate, the U.S. can still balance the economic and humanitarian tradeoff in its immigration policies. For example, in economically-prosperous times in the U.S. the percentage allocation for visas can favor the entry of skilled workers to complement the increased labor demand and the expansion of U.S. industries. However, in poorer U.S. economic conditions, this visa percentage can shift to prefer the entrance of those who qualify under the family-reunification parameter, allowing family and friends to visit their counterparts in the U.S. In this way, migration motivated by the manifestations of social capital theory will be limited and only widely authorized amid an unfavorable U.S. economic environment. However, the specifics of when to change these parameters and to what degree need to be further debated and conceptualized at the legislative level. The flexibility of this approach serves a binational purpose: while the U.S. can manage who has legal access to enter the country and for what reason, Mexican migrants can more easily participate in the U.S. labor force unattested without familiar ties and still be able to cross to visit relatives.

\section{Conclusion}

The U.S. dynamics of Mexican immigration represent a multifaceted and complex issue derived from the misguided efforts of political agendas, the sudden rise in anti-immigrant hysteria, and the overall lack of genuine understanding of the Mexican perspective. The political, economic, and geographical connectivity shared between the U.S. and Mexico indicates unilateral policy decisions that do not consider the role of the Mexican immigrant cannot easily disrupt the inherent transnational migration between the two countries. To gain insight into the Mexican migrant's perspective, this research links the micro- and macro-level forces which influence an individual's decision to migrate to the U.S. This nuanced framework aims to understand the frame of reference 
of the human subjects who willingly participate in this upward migratory flow and analyze how changes in the macroeconomic environment impact their migration decisions. Results indicate Mexicans' motivations to migrate to the U.S. are strongly impacted by U.S. macroeconomic conditions and suggest future policy considerations, such as foreign direct investment, temporary worker visa programs, and new parameters for the current U.S. visa allocation system, should reflect Mexicans' rationale in deciding to migrate. This approach to identifying the causal factors of Mexican immigration by incorporating the decision-making processes of the Mexican migrants themselves deviates from traditional research methods and legislative practices. However, to create and implement a more effective U.S. immigration strategy, Mexicans' intentions to migrate need to be capitalized on to mirror the reality of the immigration crisis.

In terms of limitations for this study, there existed several shortcomings in the selected database as observations from the years 2010 to 2016 could only be used for statistical analysis. An improved data set would include reliable information for prior years to determine if the occurrence of significant macroeconomic declines experienced in the U.S. or Mexico would influence Mexicans' motivations to migrate to the U.S. Specifically, if the data were available for the years during and following Mexico's financial crisis in 1994 (sparked by the sudden devaluation of the peso and the ramifications of capital flight), it could be determined if this economic slow-growth in Mexico represented a "supply-push" factor, prompting Mexican residents to readily participate in international migration to the U.S. Additionally, if data were available during the years of the U.S. Great Recession, it could potentially provide a further testament to the strength of U.S. macroeconomic conditions in influencing Mexicans' migration decisions. Access to data that includes motivations for migrating for these specified years can paint a more comprehensive picture in how macroeconomic conditions help determine whether Mexicans migrate to the U.S. and for what reasons.

While this research defines U.S. macroeconomic indicators as potent forces impacting Mexicans' decision to migrate, further research needs to focus on how this information is communicated to the prospective Mexican migrant population. Studies speculating the mechanism to which U.S. macroeconomic conditions are transmitted can reveal the potential informationexchange channels migrants leverage to evaluate the favorability of crossing, the type of knowledge shared, and its directional flow among stakeholders. For instance, it can be hypothesized that Mexican residents do not research this U.S. macro-level data through analyzing 
business-focused news outlets like the Wall Street Journal. Instead, prospective Mexican migrants more likely trust the aggregate experience and expertise of their social networks to provide insight into the U.S. economic climate. Additionally, social network members may not necessarily express favorable U.S. economic conditions in terms of macroeconomic indicators (such as unemployment rates and GDP growth rates) to members across the border. To gauge the health of the U.S.'s economy, favorability in migrating is perhaps relayed in terms of employment availability. Specifically, migratory networks possibly help connect potential migrants to specific jobs within an industry well-known by its own members rather than simply giving general prospects for the U.S. labor force. Overall, future research understanding the mechanism of these demand-pull forces can further disclose the complexity in the transfer of migration-specific information and the logistical nature and influential function of these social networks. 


\section{References}

America First Foreign Policy. (2017, March 08). Retrieved May 21, 2017, from https://www.whitehouse.gov/america-first-foreign-policy

Anderson, J. B., \& Gerber, J. (2008). Fifty years of change on the U.S.-Mexico border: Growth, development, and quality of life. Austin, TX: University of Texas Press.

Associated Press. (2016, February 3). Mexico Got More Money from Remittances Than from Oil Revenues in 2015. Retrieved May 7, 2017, from http://www.nbcnews.com/news/latino/mexico-got-more-money-remittances-oil-revenues2015-n510346

Borjas, G. J. (1990). Friends or strangers: The impact of immigrants on the U.S. economy. New York, NY: Basic Books.

Borjas, G. (1994, December). The Economics of Immigration. Journal of Economic Literature, 32(4), 1667-1717. Retrieved September 12, 2016, from JSTOR.

Borjas, G. J., \& Katz, L. F. (2005, April). The Evolution of the Mexican-Born Workforce in the United States. National Bureau of Economic Research. Retrieved November 15, 2016, from http://www.nber.org/papers/w11281

Browne, M. (2017, January 25). Survey: Most Mexico-Bound Cash Remittances Sent by Undocumented Workers. Retrieved May 07, 2017, from http://www.cnsnews.com/news/article/mark-browne/survey-shows-most-billions-mexicobound-cash-remittances-each-year-are-sent

Diamond, J. (2015, June 17). Donald Trump is running for president in 2016. Retrieved May 07, 2017, from http://www.cnn.com/2015/06/16/politics/donald-trump-2016-announcementelections/

Durand, J., \& Massey, D. S. (2010, July 29). New World Orders: Continuities and Changes in Latin American Migration. The ANNALS of the American Academy of Political and Social Science, 630(1), 20-52. doi:10.1177/0002716210368102

El Colegio de la Frontera Norte (COLEF). (2013). Encuesta sobre Migración en la Frontera Norte de México, 2011: Serie anualizada 2004 a 2011 (Publication). Mexico.

Escobar-Latapi, A. (2016). Mexican Social Policy and Return Migration (O. Mogollon-Lopez, Ed.). In H. Romo (Ed.), Mexican Migration to the United States (pp. 219-240). Austin, TX: University of Texas Press.

Faux, J. (2017, February 23). Trump is right to criticize NAFTA-but he's totally wrong about why it's bad for America. Retrieved May 21, 2017, from https:/qz.com/917175/trump-isright-to-criticize-nafta-but-hes-totally-wrong-about-why-its-bad-for-american-workers/ 
Fernandez-Kelly, P., \& Massey, D. S. (2007, March 01). Borders for Whom? The Role of NAFTA in Mexico-U.S. Migration. The ANNALS of the American Academy of Political and Social Science, 610(1), 98-118. doi:10.1177/0002716206297449

Fix, M., \& Passel, J. S. (1994). Immigration and immigrants: Setting the record straight. Washington, D.C.: Urban Institute.

Fukuyama, F. (2001, February). Social capital, civil society and development. Third World Quarterly, 22(1), 7-20. doi:10.1080/713701144

Hernandez, K. L. (2009). Mexican Immigration to the United States. OAH Magazine of History, 23(4), North American Migrations, 25-29. Retrieved May 21, 2017.

Light, M. T., \& Togunde, D. (2008, Autumn). The Mexican Immigration Debate: Assimilation and Public Policy. International Review of Modern Sociology, 34(2), 279-293.

Massey, D. S., Durand, J., \& Malone, N. J. (2003). Beyond smoke and mirrors: Mexican immigration in an era of economic integration. New York, NY: Russell Sage Foundation.

Massey, D. S., \& Espinosa, K. E. (1997, January). What's Driving Mexico-U.S. Migration? A Theoretical, Empirical, and Policy Analysis. American Journal of Sociology, 102(4), 939999. doi:10.1086/231037

Massey, D. S., \& Riosmena, F. (2010, July). Undocumented Migration from Latin America in an Era of Rising U.S. Enforcement. The Annals of the American Academy of Political and Social Science, 630, 294-321. Retrieved September 5, 2016, from JSTOR.

Passel, J. S., \& Cohn, D. (2016, September 20). Overall Number of U.S. Unauthorized Immigrants Holds Steady Since 2009. Retrieved May 07, 2017, from http://www.pewhispanic.org/2016/09/20/overall-number-of-u-s-unauthorizedimmigrants-holds-steady-since-2009/

Pew Research Center. (2016, November 03). Unauthorized immigrant population trends for states, birth countries and regions. Retrieved May 07, 2017, from http://www.pewhispanic.org/interactives/unauthorized-trends/

U.S. Bureau of Labor Statistics. (2012, February). The Recession of 2007-2009. Retrieved May 7, 2017, from https://www.bls.gov/spotlight/2012/recession/pdf/recession_bls_spotlight.pdf

Ye Hee Lee, M. (2015, July 08). Donald Trump's false comments connecting Mexican immigrants and crime. Retrieved May 07, 2017, from https://www.washingtonpost.com/news/fact-checker/wp/2015/07/08/donald-trumps-falsecomments-connecting-mexican-immigrants-and-crime/?utm_term $=.79 \mathrm{~b} 407 \mathrm{ba} 8 \mathrm{c} 27$ 
Running Head: CONSIDERATIONS FOR MEXICAN IMMIGRATION POLICY REFORM

\section{Appendix}

Figure 1: Estimated unauthorized immigrant population in the U.S. from 1990-2014

14

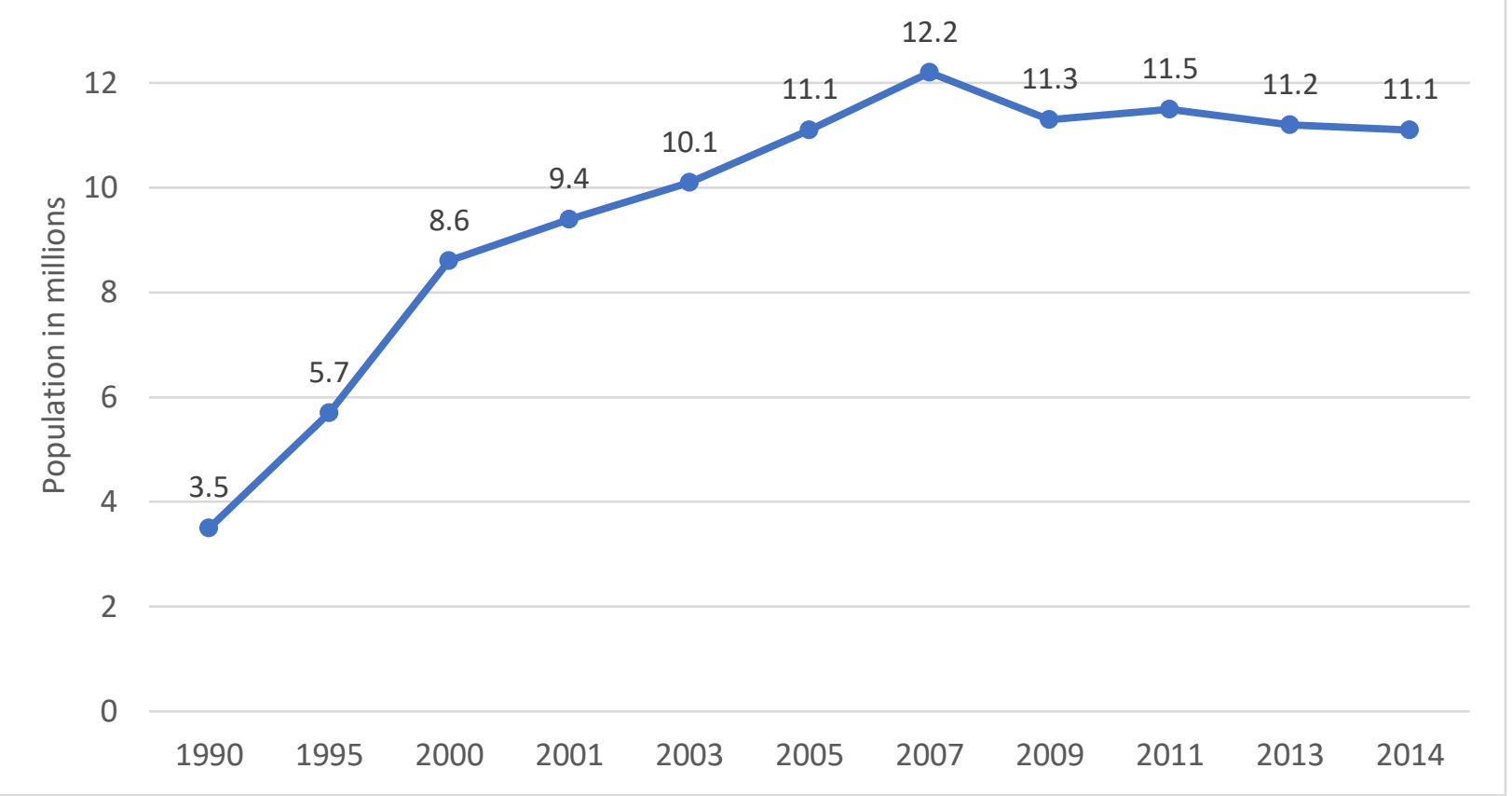

Source: Pew Research Center estimates for 2005-2014 based on augmented American Community Survey data from Integrated Public Use Microdata Series (IPUMS); for 1995 and 2004 based on March Supplements to Current Population Survey. Estimates for 1990 from Warren and Warren (2013). "Overall Number of U.S. Unauthorized Immigrants Holds Steady Since 2009" 
Running Head: CONSIDERATIONS FOR MEXICAN IMMIGRATION POLICY REFORM

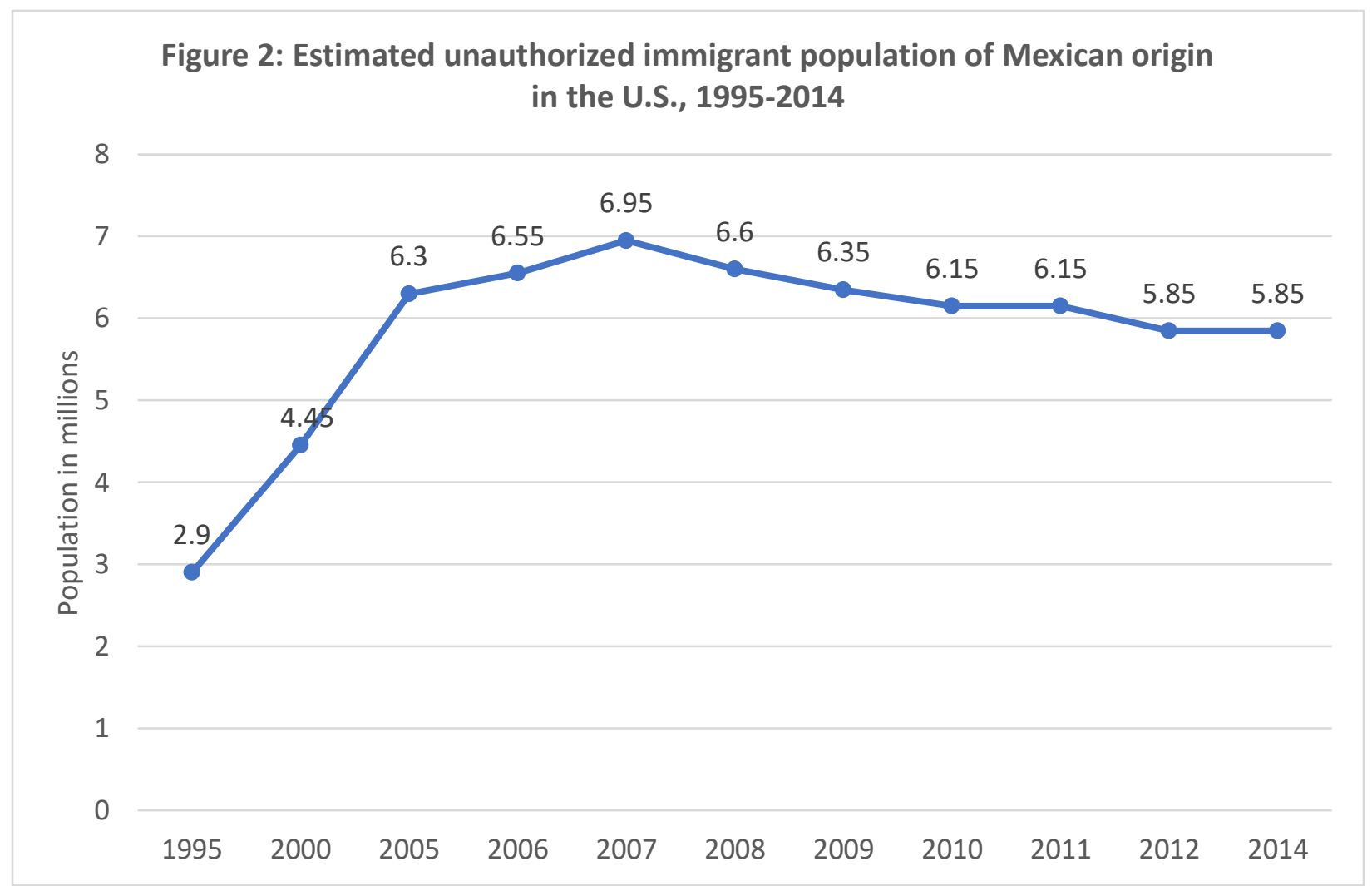

Source: Pew Research Center estimates for 2005-2014 based on augmented American Community Survey data from Integrated Public Use Microdata Series (IPUMS); for 1995 and 2000 based on March supplements to Current Population Survey; for 1990 from Warren and Warren (2013) and U.S. Immigration and Naturalization Service (2003). 
Running Head: CONSIDERATIONS FOR MEXICAN IMMIGRATION POLICY REFORM

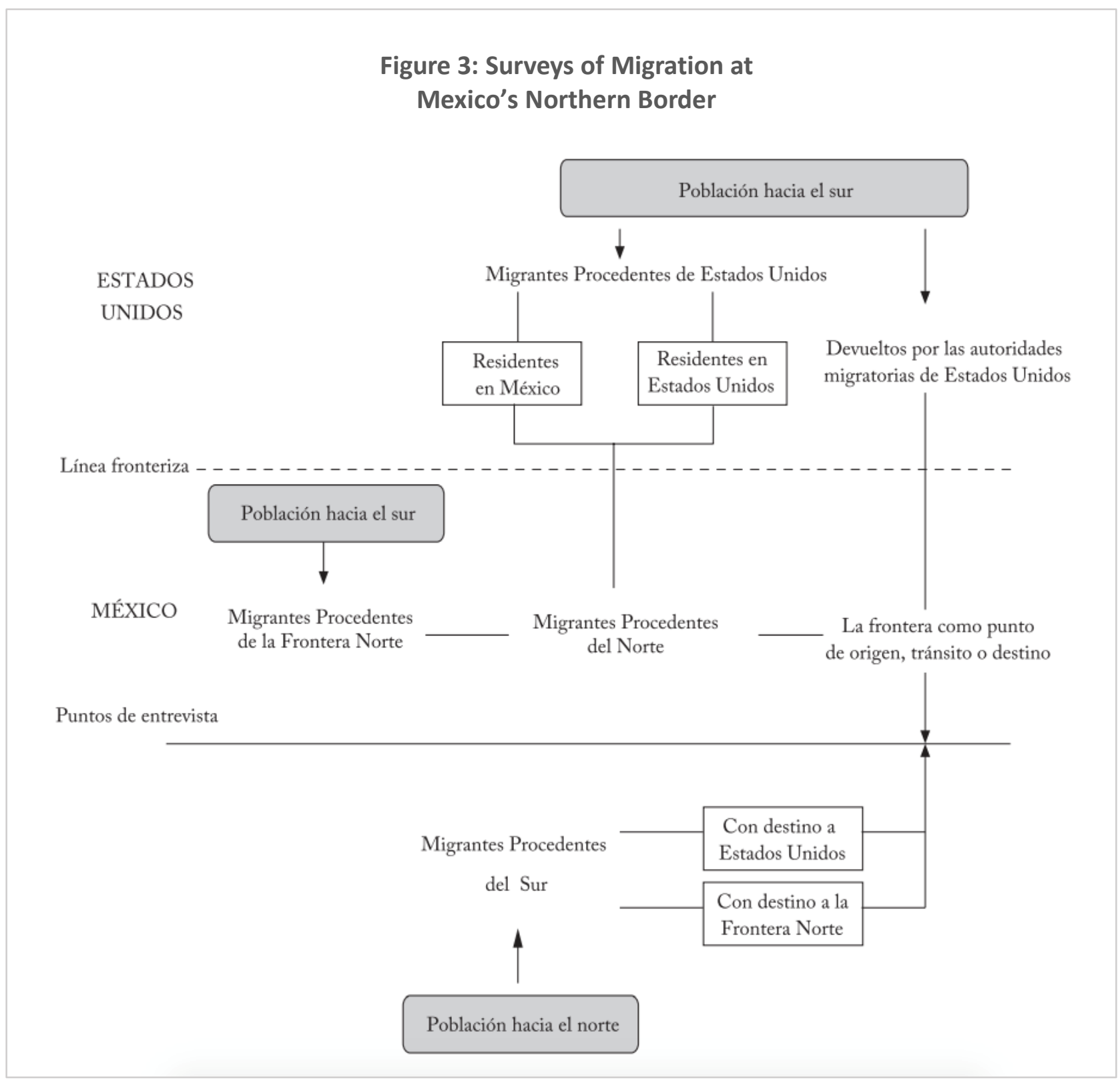

Source: Encuesta sobre Migración en la Frontera Norte de México, 2011 by El Colegio de la Frontera Norte and Mexican governmental department affiliates with some translations (p. 42). 


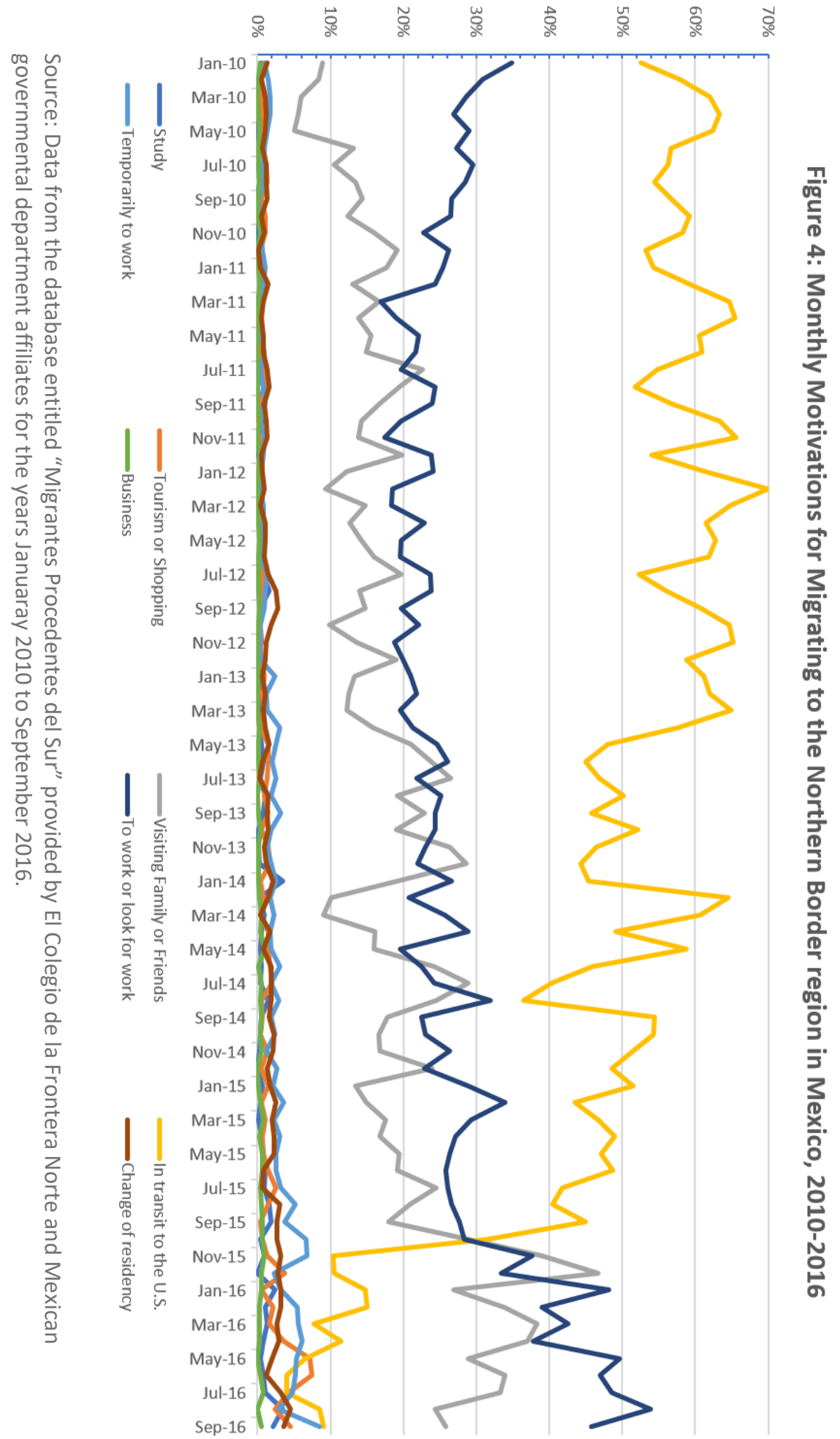




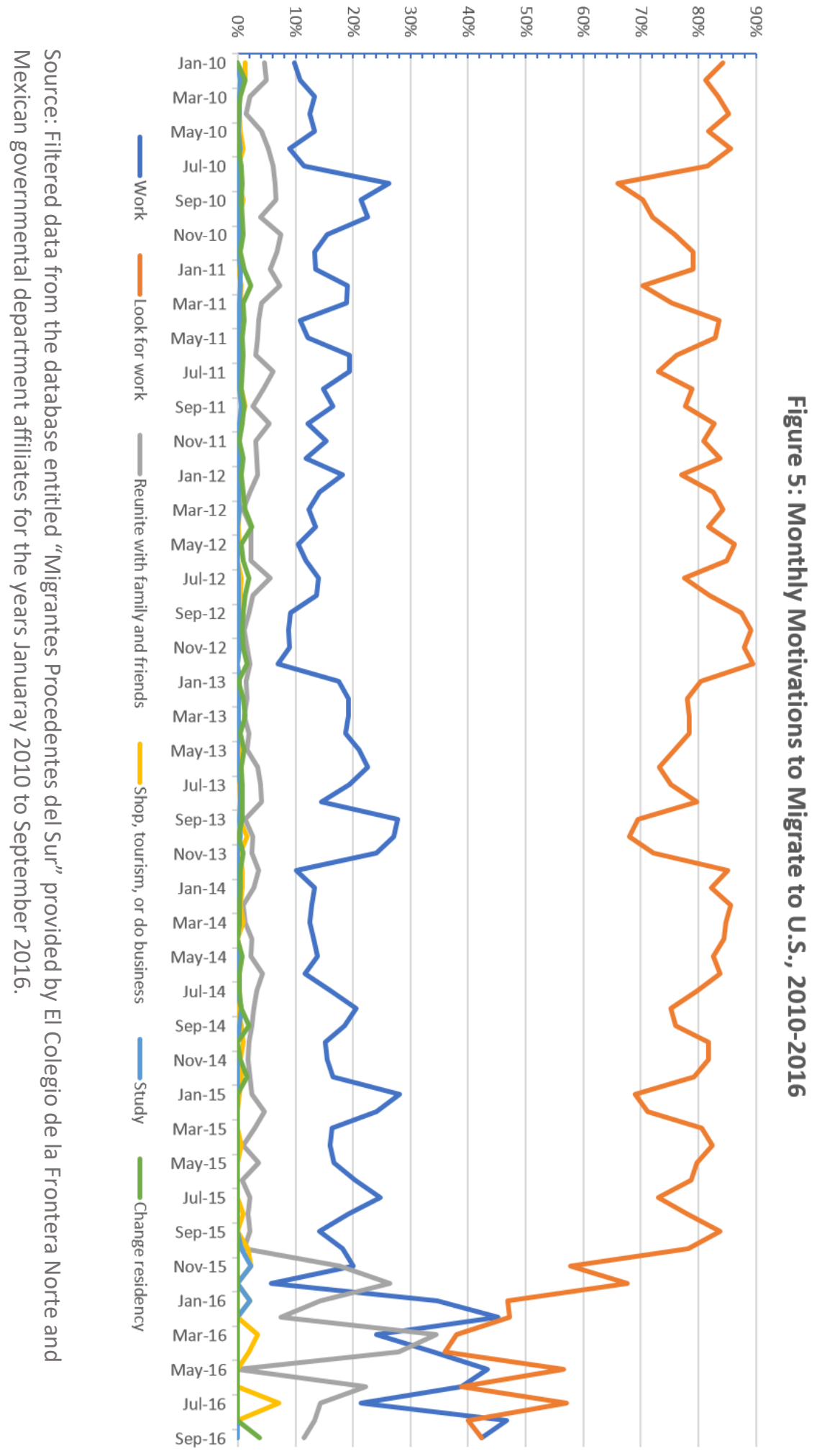




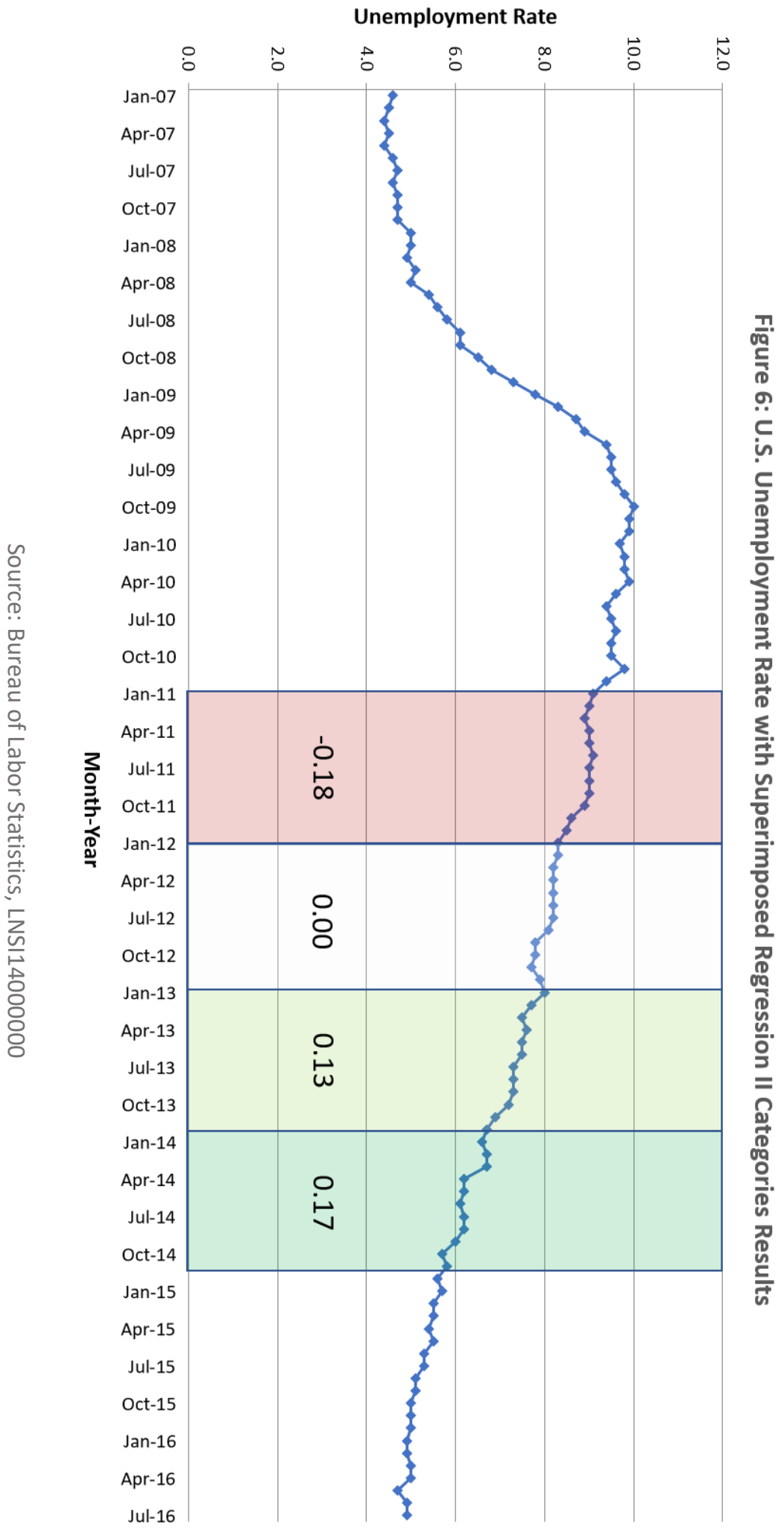


Running Head: CONSIDERATIONS FOR MEXICAN IMMIGRATION POLICY REFORM

Table 1. Descriptive Statistics

\begin{tabular}{|c|c|c|c|c|c|}
\hline Variable & Description & Mean & Std Dev & Min & Max \\
\hline \multicolumn{6}{|c|}{ Dependent Variables } \\
\hline Economic Motivation & $\begin{array}{l}\text { Reason for migrating is to work or look for } \\
\text { work in the U.S. }\end{array}$ & .9527228 & .2122335 & 0 & 1 \\
\hline $\begin{array}{l}\text { Familiar (Non- } \\
\text { economic) Motivation }\end{array}$ & $\begin{array}{l}\text { Reason for migrating is to reunite with } \\
\text { family and friends in the U.S. }\end{array}$ & 0.047209 & .2120881 & 0 & 1 \\
\hline \multicolumn{6}{|c|}{ Demographic Characteristics } \\
\hline Male & Dummy: Gender is male & .943749 & .2304084 & 0 & 1 \\
\hline Younger than 30 & $\begin{array}{l}\text { Dummy: Migrant is younger than } 30 \text { years } \\
\text { old }\end{array}$ & .5877956 & .4922372 & 0 & 1 \\
\hline Older than 30 & Dummy: Migrant is older than 30 years old & .4122044 & .4922372 & 0 & 1 \\
\hline Can Read/Write & Dummy: Migrant can read or write & .9392053 & .2389561 & 0 & 1 \\
\hline Speak English & Dummy: Migrant can speak English & .1413318 & .3483674 & 0 & 1 \\
\hline \multicolumn{6}{|c|}{ Migration-Specific Variables } \\
\hline Crossed Alone & $\begin{array}{l}\text { Dummy: Migrant crossed the U.S.-Mexico } \\
\text { border by themselves }\end{array}$ & .5702797 & .4950418 & 0 & 1 \\
\hline Frequency of Cross & $\begin{array}{l}\text { How many times migrants have crossed } \\
\text { the U.S.-Mexico border in their lifetime }\end{array}$ & .7958289 & 3.572197 & 0 & 96 \\
\hline \multicolumn{6}{|c|}{ Macroeconomic Variables } \\
\hline US UR & U.S. monthly unemployment rate & 0.0813575 & 0.0129467 & 0.047 & 0.099 \\
\hline MX UR & Mexico's monthly unemployment rate & 0.049892 & .0039174 & 0.037 & 0.058 \\
\hline US GR & U.S. quarterly GDP growth rate & 2.075764 & 1.670129 & -1.5 & 5 \\
\hline$M X G R$ & Mexico's quarterly GDP growth rate & .8262035 & .4644177 & -.8 & 1.5 \\
\hline
\end{tabular}


Running Head: CONSIDERATIONS FOR MEXICAN IMMIGRATION POLICY REFORM

Table 2. Regression Results

\begin{tabular}{|c|c|c|c|c|c|c|}
\hline \multirow[t]{2}{*}{ Variable } & \multicolumn{2}{|c|}{$\begin{array}{l}\text { Model Results I } \\
\text { (D.V. is Economic } \\
\text { Motivation) }\end{array}$} & \multicolumn{2}{|c|}{$\begin{array}{l}\text { Model Results II } \\
\text { (D.V. is Economic } \\
\text { Motivation) }\end{array}$} & \multicolumn{2}{|c|}{$\begin{array}{c}\text { Model Results III } \\
\text { (D.V. is Non-economic } \\
\text { Motivation) }\end{array}$} \\
\hline & $\begin{array}{l}\text { Estimated } \\
\text { Coefficient }\end{array}$ & Std. Error & $\begin{array}{l}\text { Estimated } \\
\text { Coefficient }\end{array}$ & Std. Error & $\begin{array}{l}\text { Estimated } \\
\text { Coefficient }\end{array}$ & Std. Error \\
\hline Male & $1.679895^{a}$ & 0.0296375 & $1.680594^{\mathrm{a}}$ & 0.0297024 & $-1.764618^{a}$ & 0.0329285 \\
\hline Younger than 30 & $.2102893^{a}$ & 0.0240769 & $.2086761^{a}$ & 0.0241453 & & \\
\hline Older than 30 & & & & & $.441137^{a}$ & 0.0292451 \\
\hline Crossed Alone & -0.0054345 & 0.0243047 & -0.0070667 & 0.0243066 & $.2166771^{\mathrm{a}}$ & 0.0301816 \\
\hline Can Read/Write & $-.2962122^{a}$ & 0.0612327 & $-.2879759^{a}$ & 0.0614939 & 0.0977304 & 0.0648071 \\
\hline Speak English & $-.4322538^{a}$ & 0.0287681 & $-.443851^{a}$ & 0.0289016 & $.3693613^{a}$ & 0.0340273 \\
\hline Frequency of Cross & $-0.0097066^{a}$ & 0.0022946 & $-0.0093325^{a}$ & 0.0022931 & $0.0143231^{a}$ & 0.0022766 \\
\hline US UR & $-6.576514^{a}$ & 1.263438 & & & $7.80216^{\mathrm{a}}$ & 1.503515 \\
\hline MX UR & -2.125079 & 3.665727 & & & -.8329301 & 4.38243 \\
\hline US GR & $0.0225997^{a}$ & 0.0069179 & & & -0.0025953 & 0.008426 \\
\hline$M X G R$ & -0.0215119 & 0.0282411 & & & 0.0434397 & 0.0343667 \\
\hline 2010 & & & $-.146437^{a}$ & 0.0515596 & & \\
\hline 2011 & & & $-.1846864^{a}$ & 0.0505503 & & \\
\hline 2012 & & & 0.0767833 & 0.0525185 & & \\
\hline 2013 & & & $.1348764^{b}$ & 0.057031 & & \\
\hline 2014 & & & $.166368^{a}$ & 0.0617914 & & \\
\hline
\end{tabular}

Notes: $a, b$, and c indicate significance at the $0.01,0.05$ and 0.10 levels, respectively. Reference categories for Model II are the years 2015 and 2016. 